Correspondence

Shuang-Jiang Liu shuangjiang@hotmail.com

\section{Planomicrobium chinense sp. nov., isolated from coastal sediment, and transfer of Planococcus psychrophilus and Planococcus alkanoclasticus to Planomicrobium as Planomicrobium psychrophilum comb. nov. and Planomicrobium alkanoclasticum comb. nov.}

\author{
Xin Dai, Ya-Nan Wang, Bao-Jun Wang, Shuang-Jiang Liu \\ and Yu-Guang Zhou \\ State Key Laboratory of Microbial Resources at the Institute of Microbiology, Chinese \\ Academy of Sciences, Zhong-Guan-Cun, Haidian, Beijing 100080, PR China
}

Aerobic, Gram-positive, motile cocci or rods were classified as members of the genus Planococcus before the genus Planomicrobium was established (Nakagawa et al., 1996). At present, the genus Planomicrobium includes the following species: Planomicrobium momeekinii (Junge et al., 1998), Planomicrobium okeanokoites (Nakagawa et al., 1996) and Planomicrobium koreense (Yoon et al., 2001). Two species belonging to the genus Planococcus, Planococcus psychrophilus (Reddy et al., 2002) and Planococcus alkanoclasticus (Engelhardt et al., 2001), may also be members of the genus Planomicrobium (Yoon et al., 2003). During an ecological survey of the microbial diversity of coastal

The GenBank/EMBL/DDBJ accession number for the $16 \mathrm{~S}$ rRNA gene sequence of strain DX3-12 $2^{\top}$ is AJ697862. sediments from the Eastern China Sea in Fujian Province, China, a nitrate-reducing isolate, strain DX3-12 ${ }^{\mathrm{T}}$, was obtained. Characterization and classification of this isolate is described.

Strain DX3-12 ${ }^{\mathrm{T}}$ was isolated from coastal sediment of the Eastern China Sea. Samples (4-6 cm beneath surface) were diluted with $9 \mathrm{ml}$ sterile saline solution and $10^{-3}$ and $10^{-4}$ dilutions $(0 \cdot 1 \mathrm{ml})$ were plated onto artificial sea water basal medium with $1 \%$ peptone and $0.5 \%$ yeast extract (Eguchi et al., 1996). Routine cultivation of strain DX3-12 ${ }^{\mathrm{T}}$ was done at $30{ }^{\circ} \mathrm{C}$ in marine broth 2216 (MB; Difco). Observation of the morphology of strain DX3-12 ${ }^{\mathrm{T}}$ was carried out with optical (Olympus BX51) and scanning electron (Hitachi S-570) microscopes. Physiological and biochemical tests, including catalase and oxidase activities, decomposition of 
gelatin and casein and hydrolysis of starch were determined by the methods of Cowan \& Steel (1965). Nitrate reductase production was evaluated as described by Lanyi (1987). $\mathrm{NaCl}$ tolerance was investigated by supplementing $\mathrm{MB}$ with various $\mathrm{NaCl}$ concentrations. The temperature and $\mathrm{pH}$ ranges for growth were determined in MB.

Biomass for chemotaxonomic analysis was harvested from $\mathrm{MB}$ cultures on a rotary shaker $\left(100\right.$ r.p.m., $\left.30^{\circ} \mathrm{C}\right)$. Preparation of cell walls and determination of peptidoglycan structure were carried out using the methods of Schleifer \& Kandler (1972). Menaquinones were extracted and purified according to Collins (1985) and were analysed by HPLC (Wu et al., 1989) with Planomicrobium mcmeekinii as the reference. The fatty acid profile of whole cells was analysed by GC with a model HP6890 equipped with a hydrogen ionization detector (FID). Peaks were identified with preinstalled software, HPCHEM-STATION (version A5.01).

Genomic DNA of strain DX3-12 ${ }^{\mathrm{T}}$ was extracted according to Marmur (1961) and G+C content (mol\%) was determined by thermal denaturation, with Escherichia coli K-12 as the reference. The $16 \mathrm{~S}$ rRNA gene of strain DX3-12 $2^{\mathrm{T}}$ was amplified and sequenced as described previously (Zhang et al., 2003). Alignments of $16 \mathrm{~S}$ rRNA gene sequences of strain DX3 $-12^{\mathrm{T}}$ and other type strains of the genera Planomicrobium and Planococcus were carried out with CLUSTAL X version 1.8 (Thompson et al., 1997). Evolutionary distance calculations were performed according to Kimura (1980). Phylogenetic trees were constructed according to the neighbour-joining (Saitou \& Nei, 1987) and maximumparsimony tree-making algorithms in the PHYLIP software package (Felsenstein, 1993). Positions 31-1431 (E. coli numbering) were used in all phylogenetic analyses. DNA relatedness was determined by the method of De Ley et al. (1970).

Cells of strain DX3 $-12^{\mathrm{T}}$ were cocci or short rods, $0 \cdot 8 \times$ $1.0 \mu \mathrm{m}$. Detailed phenotypic properties are given in the species description. Physiological and biochemical characteristics of this strain that enable it to be distinguished from other type strains of Planomicrobium species are listed in Table 1. The cell wall composition of strain DX3 $-12^{\mathrm{T}}$ was determined and contained L-lysine, L-aspartic acid, Lglutamic acid and alanine, but not L-ornithine; this is consistent with the A4 $\alpha$ type (Schleifer \& Kandler, 1972) cell wall of Planomicrobium. The major menaquinones were MK-8 and MK-7, with a peak area ratio of $55: 8$. Cells of strain DX3-12 ${ }^{\mathrm{T}}$ grown in MB contained anteiso- $\mathrm{C}_{15: 0}$ $(49 \cdot 7 \%)$ as the major fatty acid and significant amounts of $\mathrm{C}_{16: 1} \omega 7 c$ alcohol $(12 \cdot 1 \%)$. The genomic DNA G $+\mathrm{C}$ content was $34 \cdot 8 \mathrm{~mol} \%$.

The nearly complete $16 \mathrm{~S}$ rRNA gene (1510 bp) of strain DX3 $-12^{\mathrm{T}}$ was cloned and sequenced. Phylogenetic analysis based on 16S rRNA gene sequence similarity showed that strain DX3 $-12^{\mathrm{T}}$ was closely related to members of the genus Planomicrobium [Planomicrobium momeekinii (97.8\% similarity), Planomicrobium koreense $(97 \cdot 8 \%)$ and Planomicrobium okeanokoites $(97 \cdot 1 \%)]$ and to members of the genus Planococcus [Planococcus psychrophilus (97.5\%), Planococcus alkanoclasticus (96.4\%) and Planococcus stackebrandtii (96.3\%) (Mayilraj et al., 2005)]. These species gathered and formed a cluster with moderate bootstrap support, as indicated by either neighbour-joining (Fig. 1) or maximum-parsimony (data not shown). Strain DX3$12^{\mathrm{T}}$ could be distinguished phenotypically from other Planomicrobium species (Table 1). DNA relatedness to Planomicrobium momeekinii DSM $13963^{\mathrm{T}}$, a phylogenetically related and phenotypically similar species, was $35 \cdot 4 \%$. DNA-DNA hybridization to other species of Planomicrobium was not attempted because of the large differences in $\mathrm{G}+\mathrm{C}$ content between these species and strain DX3-12 ${ }^{\mathrm{T}}$ (11.5-12.2\%; Table 1). Based on the above characteristics, strain DX3-12 $2^{\mathrm{T}}$ was identified as a representative of a novel species of Planomicrobium; the name Planomicrobium chinense sp. nov. is proposed.

$16 \mathrm{~S}$ rRNA gene sequence analyses of this and previously studied strains (Yoon et al., 2003) showed that two members

Table 1. Differential phenotypic properties of strain $D X 3-12^{\top}$ and other type strains of Planomicrobium species

Taxa: 1, DX3-12 ${ }^{\mathrm{T}}$; 2, Planomicrobium koreense; 3, Planomicrobium mcmeekinii; 4, Planomicrobium okeanokoites; 5, Planomicrobium alkanoclasticum comb. nov.; 6, Planomicrobium psychrophilum comb. nov. (data from references listed). +, Positive; -, negative; w, weakly positive; NR, not reported.

\begin{tabular}{|c|c|c|c|c|c|c|}
\hline Property & 1 & 2 & 3 & 4 & 5 & 6 \\
\hline Cell shape & Coccoid/short rods & Coccoid/rods & Coccoid/rods & Rods & Rods & Rods \\
\hline \multicolumn{7}{|l|}{ Growth at/in: } \\
\hline Temperature $\left({ }^{\circ} \mathrm{C}\right)$ & $12-43$ & $4-38$ & $0-37$ & $20-37$ & $15-41$ & $0-30$ \\
\hline $\mathrm{NaCl}(\%)$ & $0-10$ & $0-7$ & $0-7$ & $0-7$ & $0 \cdot 8-6$ & $0-12$ \\
\hline Oxidase & - & - & - & $\mathrm{W}$ & - & + \\
\hline Nitrate reduction & + & - & + & - & - & - \\
\hline Aesculin hydrolysis & - & + & $\mathrm{NR}$ & - & NR & + \\
\hline Acid production from glucose & - & $\mathrm{W}$ & + & - & - & - \\
\hline $\mathrm{G}+\mathrm{C}$ content $(\mathrm{mol} \%)$ & $34 \cdot 8$ & 47 & 35 & $46 \cdot 3$ & $45 \cdot 3$ & $44 \cdot 5$ \\
\hline
\end{tabular}




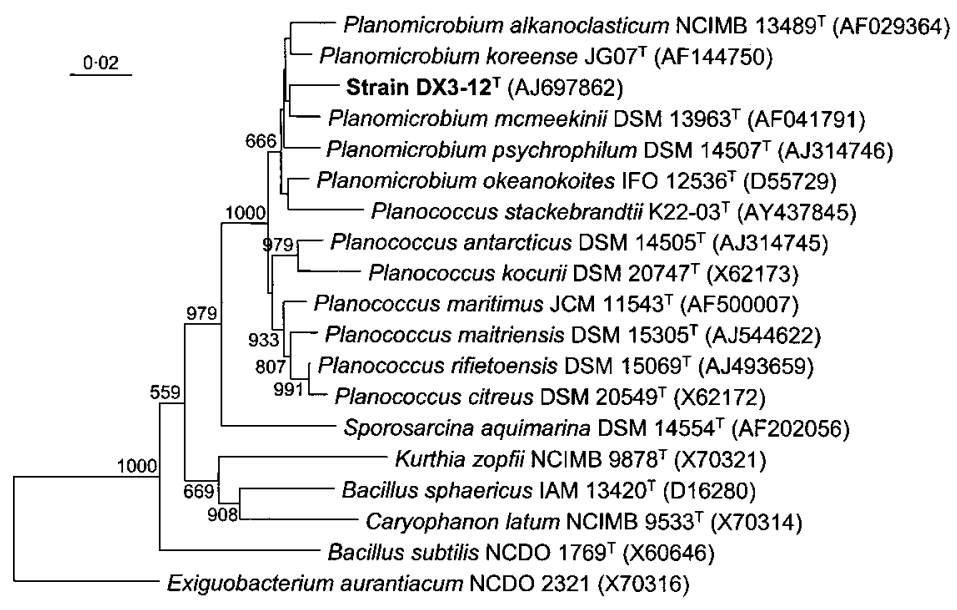

Fig. 1. Neighbour-joining tree based on 16S rRNA gene sequence analysis showing phylogenetic relationships between strain DX3-12 ${ }^{\top}$, other related species of the genera Planomicrobium and Planococcus, and related reference organisms. Bootstrap confidence values greater than 500 obtained from 1000 bootstrap replications are given at the nodes. Bar, 0.02 substitutions per nucleotide position.

of the genus Planococcus, Planococcus psychrophilus and Planococcus alkanoclasticus, clustered with members of the genus Planomicrobium, rather than with members of the genus Planococcus. This clustering is consistently supported by different tree construction methods. When the $16 \mathrm{~S}$ rRNA gene sequences were further examined, these two species were shown to have sequence signatures at positions 183 and 190 (E. coli numbering) indicative of Planomicrobium rather than Planococcus (Table 2). In addition, cells of these two species are rods, unlike members of the genus Planococcus, which have coccoid cells. Thus, these two species are here transferred to the genus Planomicrobium as Planomicrobium psychrophilum comb. nov. and Planomicrobium alkanoclasticum comb. nov. The very recently described species Planococcus stackebrandtii (Mayilraj et al., 2005) also clustered within the Planomicrobium group (Fig. 1) and had Planomicrobium signature nucleotides at positions 183 and 190; this species may possibly be a member of the genus Planomicrobium.

\section{Description of Planomicrobium chinense sp. nov.}

Planomicrobium chinense (chin.en'se. N.L. neut. adj. chinense pertaining to China, where the type strain was isolated and studied).

Cells are coccoid or short rods, $0 \cdot 8 \times 1 \cdot 0 \mu \mathrm{m}$. Gram-positive and non-spore-forming. Motile by polar flagella. Strictly aerobic. Colonies are smooth, circular, low-convex and yellow to orange in colour when cultivated on MA. Growth occurs at $10-45^{\circ} \mathrm{C}$; optimum growth at $30-35^{\circ} \mathrm{C}$ and no growth above $46^{\circ} \mathrm{C}$. Optimal $\mathrm{pH}$ for growth is $6 \cdot 0-7 \cdot 0$; no growth occurs below $\mathrm{pH} 5 \cdot 0$ or above $\mathrm{pH} 10 \cdot 0$. Growth occurs in $0-10 \% \mathrm{NaCl}$. Gelatin is hydrolysed, but not casein, starch, Tween 80 or aesculin. Acid is produced from glucose, but not from sucrose, raffinose, lactose, arabinose, cellobiose, xylose, rhamnose, melibiose, mannose or mannitol. Citrate does not support growth. Nitrate is reduced. Cell wall is type A4 $\alpha$. Cells contain MK- 8 as major

Table 2. Sequence signatures of $16 \mathrm{~S}$ rRNA genes for type strains of species of the genera Planomicrobium and Planococcus

Common nucleotides shared by species of the genus Planomicrobium or Planococcus are shown in bold.

\begin{tabular}{|l|c|}
\hline Organism & $\mathbf{1 8 3}$ \\
\hline E. coli & C G T C G C A A G A C \\
Strain DX3-12 & $\mathbf{T}$ \\
Planomicrobium koreense (AF144750) & C C T C C T G G T G G \\
Planomicrobium okeanokoites (D55729) & C C T C C T G G G G C \\
Planomicrobium mcmeekinii (AF041791) & C C T C C T G G - G N \\
Planomicrobium psychrophilum (AJ314746) & C C T C C T G G G G C \\
Planomicrobium alkanoclasticum (AF029364) & C C T C C T G G C G A \\
Planococcus citreus (X62172) & C C T C C T G G G G C \\
Planococcus kocurii (X62173) & T C T C A T G A G G C \\
Planococcus maitriensis (AJ544622) & T C T C C T G A G G C \\
Planococcus rifietoensis (AJ493659) & T C T C A T G A G G C \\
Planococcus maritimus (AF500007) & T C T C A T G A G G C \\
Planococcus antarcticus (AJ314745) & T C T C A T G A G G C \\
\end{tabular}


menaquinone. The cellular fatty acid profile is as follows: iso- $\mathrm{C}_{14: 0}(10 \cdot 4 \%)$, anteiso- $\mathrm{C}_{15: 0}(49 \cdot 7 \%)$, iso- $\mathrm{C}_{15: 0}(3 \cdot 8 \%)$, $\mathrm{C}_{15: 0}(4 \cdot 9 \%), \mathrm{C}_{16: 1} \omega 7 c$ alcohol $(12 \cdot 1 \%)$, iso- $\mathrm{C}_{16: 0}(4 \cdot 1 \%)$, $\mathrm{C}_{16: 1} \omega 11 c(4 \cdot 5 \%), \mathrm{C}_{16: 0}(1 \cdot 5 \%)$, iso- $\mathrm{C}_{17: 1} \omega 10 c(1 \cdot 7 \%)$, iso- $\mathrm{C}_{17: 1} \mathrm{I}(4 \cdot 4 \%)$ and anteiso- $\mathrm{C}_{17: 0}(2 \cdot 8 \%)$.

The type strain, DX3-12 $2^{\mathrm{T}}\left(=\right.$ AS $\left.1.3454^{\mathrm{T}}=\mathrm{JCM} 12466^{\mathrm{T}}\right)$, was isolated from coastal sediment from the Eastern China Sea in Fujian Province, China. The DNA G + C content of the type strain is $34 \cdot 8 \mathrm{~mol} \%$.

\section{Description of Planomicrobium psychrophilum comb. nov.}

Planomicrobium psychrophilum (psy.chro.phi'lum. Gr. n. psychros cold; Gr. adj. philos loving; N.L. neut. adj. psychrophilum cold-loving).

Basonym: Planococcus psychrophilus Reddy et al. 2002.

The description is as given previously by Reddy et al. (2002). The type strain is DSM $14507^{\mathrm{T}}\left(=\right.$ MTCC $\left.3812^{\mathrm{T}}\right)$.

\section{Description of Planomicrobium alkanoclasticum comb. nov.}

Planomicrobium alkanoclasticum (al.kan.o.cla'sti.cum. N.L. n. alkanum alkane; Gr. adj. clastos broken; N.L. neut. adj. alkanoclasticum breaking alkanes).

Basonym: Planococcus alkanoclasticus Engelhardt et al. 2001.

The description is as given previously by Engelhardt et al. (2001). The type strain is NCIMB $13489^{\mathrm{T}}\left(=\mathrm{MAE}^{\mathrm{T}}=\mathrm{CIP}\right.$ $\left.107718^{\mathrm{T}}\right)$.

\section{Acknowledgements}

This work was supported by grants from National Natural Science Foundation of China and Chinese Academy of Sciences (KSCX2SW-113). We thank Professor H. Trüper at the University of Bonn, Germany, for his help with the nomenclature and etymology.

\section{References}

Collins, M. D. (1985). Isoprenoid quinone analysis in classification and identification. In Chemical Methods in Bacterial Systematics, pp. 267-287. Edited by M. Goodfellow \& D. E. Minnikin. London: Academic Press.

Cowan, S. T. \& Steel, K. J. (1965). Manual for the Identification of Medical Bacteria. London: Cambridge University Press.

De Ley, J., Cattoir, H. \& Reynaerts, A. (1970). The quantitative measurement of DNA hybridization from renaturation rates. Eur J Biochem 12, 143-153.

Eguchi, M., Ishikawa, T., MacDonald, K., Cavicchioli, R., Gottschal, J. C. \& Kjelleberg, S. (1996). Response to stress and nutrient availability by the marine ultramicrobacterium Sphingomonas sp. strain RB2256. Appl Environ Microbiol 62, 1287-1294.
Engelhardt, M. A., Daly, K., Swannell, R. P. J. \& Head, I. M. (2001). Isolation and characterization of a novel hydrocarbon-degrading, Gram-positive bacterium, isolated from intertidal sediment, and description of Planococcus alkanoclasticus sp. nov. J Appl Microbiol 90, 237-247.

Felsenstein, J. (1993). PHYLIP (phylogenetic inference package), version 3.5c. Department of Genetics, University of Washington, Seattle, WA, USA.

Junge, K., Gosink, J. J., Hoppe, H.-G. \& Staley, J. T. (1998). Arthrobacter, Brachybacterium and Planococcus isolates identified from Antarctic sea ice brine. Description of Planococcus mcmeekinii sp. nov. Syst Appl Microbiol 21, 306-314.

Kimura, M. (1980). A simple method for estimating evolutionary rates of base substitutions through comparative studies of nucleotide sequences. J Mol Evol 16, 111-120.

Lanyi, B. (1987). Classical and rapid identification methods for medically important bacteria. Methods Microbiol 19, 1-67.

Marmur, J. (1961). A procedure for the isolation of deoxyribonucleic acid from microorganisms. J Mol Biol 3, 208-218.

Mayilraj, S., Prasad, G. S., Suresh, K., Saini, H. S., Shivaji, S. \& Chakrabarti, T. (2005). Planococcus stackebrandtii sp. nov., isolated from a cold desert of the Himalayas, India. Int J Syst Evol Microbiol 55, 91-94.

Nakagawa, N., Sakane, T. \& Yokota, A. (1996). Emendation of the genus Planococcus and transfer of Flavobacterium okeanokoites Zobell and Upham 1944 to the genus Planococcus as Planococcus okeanokoites comb. nov. Int J Syst Bacteriol 46, 866-870.

Reddy, G. S. N., Prakash, J. S. S., Vairamani, M., Prabhakar, S., Matsumoto, G. I. \& Shivaji, S. (2002). Planococcus antarcticus and Planococcus psychrophilus spp. nov. isolated from cyanobacterial mat samples collected from ponds in Antarctica. Extremophiles 6, 253-261.

Saitou, N. \& Nei, M. (1987). The neighbor-joining method: a new method for reconstructing phylogenetic trees. Mol Biol Evol 4, 406-425.

Schleifer, K. H. \& Kandler, O. (1972). Peptidoglycan types of bacterial cell walls and their taxonomic implications. Bacteriol Rev 36, 407-477.

Thompson, J. D., Gibson, T. J., Plewniak, F., Jeanmougin, F. \& Higgins, D. G. (1997). The CLUSTAL_X windows interface: flexible strategies for multiple sequence alignment aided by quality analysis tools. Nucleic Acids Res 25, 4876-4882.

Wu, C., Lu, X., Qin, M., Wang, Y. \& Ruan, J. (1989). Analysis of menaquinone compound in microbial cells by HPLC. Microbiology (English translation of Mikrobiologiya) 16, 176-178.

Yoon, J.-H., Kang, S.-S., Lee, K.-C., Lee, E.-S., Kho, Y. H., Kang, K. E. \& Park, Y.-H. (2001). Planomicrobium koreense gen. nov., sp. nov., a bacterium isolated from the Korean traditional fermented seafood jeotgal, and transfer of Planococcus okeanokoites (Nakagawa et al. 1996) and Planococcus momeekinii (Junge et al. 1998) to the genus Planomicrobium. Int J Syst Evol Microbiol 51, 1511-1520.

Yoon, J.-H., Weiss, N., Kang, K.-H., Oh, T.-K. \& Park, Y.-H. (2003). Planococcus maritimus sp. nov., isolated from sea water of a tidal flat in Korea. Int J Syst Evol Microbiol 53, 2013-2017.

Zhang, D., Yang, H., Zhang, W., Huang, Z. \& Liu, S.-J. (2003). Rhodocista pekingensis sp. nov., a cyst-forming phototrophic bacterium from a municipal wastewater treatment plant. Int J Syst Evol Microbiol 53, 1111-1114. 